\title{
0 guardião do pássaro da noite: memórias de luta e solidariedade no Mocambo do Arari, Parintins (AM) ${ }^{1}$
}

\author{
Josivaldo Bentes Lima Júnior* \\ ORCID iD 0000-0003-2574-1879 \\ Secretaria de Estado de Educação e Qualidade de Ensino do Amazonas, Manaus, Brasil
}

Resumo: $\mathrm{O}$ artigo problematiza as experiências na organização e defesa da festa do cordão de pássaro Jaçanã, no Mocambo do Arari, Parintins (AM), tomando como recorte de análise as memórias de um idoso, guardiāo do pássaro, desde 1956. Em 2004, após um período de interrupçấo, com a organização do Festival Folclórico, os pássaros Jaçanã e Pavão Misterioso voltaram a brincar, contudo, foram secundarizados pelos bois-bumbás, ameaçando a continuidade da cultura identificada como "as brincadeiras dos mais velhos". No intuito de democratizar as narrativas, a pesquisa foi realizada com enfoque teórico-metodológico na história oral, ao revalorizar as experiências de sujeitos invisibilizados pelas memórias oficiais. Os resultados evidenciam as articulaçóes de um homem pobre, com pouca escolaridade, que contou com a solidariedade dos companheiros de trabalho, vizinhos e amigos que, mesmo em meio às dificuldades impostas pelo envelhecimento e as agruras de uma vida dedicada ao trabalho no campo somadas à falta de recursos financeiros e à possível desilusão de outros moradores, historicamente, se organizou em estratégias de resistência para manter a festa do pássaro, isto é, reivindicando o direito à memória e à cidadania.

Palavras-chave: Pássaros. Memória. Envelhecimento. Solidariedade. História oral.

The guardian of the night bird: memories of struggle and solidarity in Mocambo do Arari, Parintins (AM)

Abstract: The article discusses the experiences in the organization and defense of the "Jaçanâ" bird cord party, in Mocambo do Arari, Parintins (AM), taking as a fragment of the analysis, the memories of

1 Texto resultante de parte da minha pesquisa de mestrado realizada nos anos de 2017 e 2018, no Programa de Pós-graduação em História, pela Universidade Federal do Amazonas (UFAM).

* Mestre em História Social pela Universidade Federal do Amazonas (UFAM), com orientação do Prof. Dr. Nelson Tomelin Jr. E-mail: juninhobentes@hotmail.com. 
an elderly man, the guardian of the bird, since 1956. In 2004, after an interruption period, with the organization of the Folkloric Festival, the birds "Jaçanâ" and "Pavão Misterioso" returned to play, however, they have been made secondary by "bois-bumbás", threatening the continuity of the culture identified as "the games of the elders". To democratize the narratives, the research was carried out with a theoreticalmethodological focus on Oral History, by revaluing the experiences of subjects who were made invisible by official memories. The results show the articulations of a poor man, with little education, who received the solidarity of his co-workers, neighbors and friends who, even in the midst of the difficulties imposed by aging and the hardships of a life dedicated to countryside work, added to the lack of financial resources and also to the possible disillusionment of other resident, has historically been organized in resistance strategies to maintain the bird party, namely, claiming the right to memory and citizenship.

Keywords: Birds. Memory. Seniors. Solidarity. Oral History.

\section{Introdução}

O artigo problematiza as experiências de um idoso na organizaçáo e na defesa da festa do pássaro Jaçaná, no Mocambo do Arari, Parintins (AM). Protagonista de um desenrolar temporal de enfrentamento ao envelhecimento e à supressão de direitos, Milton Almeida, 83 anos, fez da cultura a sua história. Guardião do pássaro Jaçaná desde 1956, sua experiência narrativa alarga entendimentos sobre as articulaçóes de sujeitos históricos no cordáo de pássaro - cultura amadurecida por esforços de toda uma vida - na reivindicaçáo de direitos e na luta contra as tentativas de ocultação de suas experiências.

O narrador foi escolhido em virtude das referências que os demais moradores têm dele como o guardião do pássaro, pois, ainda que não tenha criado a brincadeira no local, ${ }^{2}$ ele sabia como fazê-la e reativou o cordão do Jaçanã - entáo única brincadeira local - convocando os outros trabalhadores do Mocambo do Arari. Por mais de cinquenta anos organizando a festa, o narrador apostou nos laços de solidariedade para manter viva a cultura que o identifica em seus fazeres sociais. A história de Milton Almeida narra as múltiplas estratégias de resistência para a continuidade da brincadeira, enfrentando as dificuldades impostas pelo avanço da idade, as agruras de uma vida dedicada ao trabalho no campo, a falta de recursos financeiros e a possível desilusáo dos moradores.

De forma geral, os cordōes de pássaros, em sua composição, narram a história de um pássaro de estimação que, ao ser morto por um caçador, deixa seu dono entristecido

2 A história do Jaçanã fala de seu aparecimento no Mocambo do Arari em 1952, por meio dos irmãos Messias, trabalhadores de Maués (AM), que brincavam com o pássaro nas horas de lazer, após longa jornada de trabalho na juta na região (Gomes, 2017). 
a ponto de pedir ajuda de um pajé/curandeiro para ressuscitá-lo (Moura, 1997). Os pássaros Jaçanã e Paváo Misterioso brincavam ${ }^{3}$ no calendário junino da comunidade São João do Mocambo do Arari. ${ }^{4}$ Em 1994, no entanto, os pássaros e os bois-bumbás foram impedidos pelo pároco de se apresentarem no arraial festivo ao santo, devido aos aspectos da religiosidade afro-indígena presentes na festa. Com a organização do festival, em 2004, os pássaros voltaram a se apresentar, mas os bois-bumbás se tornaram a principal atração do lugar, ameaçando a continuidade dos outros grupos culturais. Secundarizados, então, os pássaros passaram a enfrentar mais dificuldades para a sua manutenção, uma vez que há perda de interesse dos mais jovens. Por outro lado, no dia da apresentação dos pássaros - sexta-feira -, observei que as arquibancadas do Mocambodromo ${ }^{5}$ reuniam um grupo considerável de idosos e idosas, cujas emoçóes saltavam aos olhos. Muitos deles preferiam estar de pé, vibrando, cantando e dançando as músicas apresentadas ali, justificando as referências locais de tratar-se das "brincadeiras dos mais velhos". Diante dessas perspectivas, questionei-me: qual a importância da festa e quais as articulaçóes de resistência para a continuidade da brincadeira?

No intuito de democratizar as narrativas, a pesquisa foi realizada com enfoque teórico-metodológico na história oral, por revalorizar as experiências de sujeitos invisibilizados pelas memórias oficiais. Quer-se aqui evidenciar as articulaçóes de um idoso pobre, com pouca escolaridade, morador de uma comunidade rural amazônica, que apostou na solidariedade como alternativa de enfrentamento à ocultação de seus fazeres sociais, articulando estratégias de resistências e luta por direitos eventualmente negados, juntos dos companheiros de trabalho, isto é, vivências estas que pluralizam as experiências de trabalhadores que compartilham interesses, valores e consciência coletiva (Thompson, 1998).

Bosi (1994) escreve sobre a necessidade de ouvir as vozes de pessoas idosas, ao formarem quadros sociais em que se produz a memória em seu trabalho de refazê-la, isto é, a função social de lembrar e compreender o passado. Por fim, é preciso "ouvir a voz dos excluídos e dos esquecidos; trazer à luz as realidades 'indescritíveis', quer dizer, aquelas que a escrita náo consegue transmitir; testemunhar situaçóes de extremo abandono" (Joutard, 2000, p. 33).

3 A brincadeira consiste na organização dos dançarinos enfileirados, formando um cordão em que o pássaro se apresenta ao meio deles.

4 Organizada primeiramente em comunidade por meio da Congregação Mariana - o nome faz referência à devoção ao santo que já ocorria na região -, passou a status de vila, sede do distrito Mocambo do Arari, em 1978, onde o acesso é restrito a vias fluviais, com viagens que podem durar três horas em lanchas rápidas ou seis horas em barcos maiores. $\mathrm{O}$ distrito é habitado por cerca de 10 mil pessoas, organizadas em comunidades (Cerqua, 2009; Silva, 2009; Gomes, 2017).

5 Espaço Cultural Victor Mendonça, arena de apresentações das agremiações culturais. O local comporta cerca de 2 mil espectadores. O nome faz alusão ao "Bumbódromo" de Parintins. Optei por manter a grafia original, conforme registrado localmente. 


\section{História oral, memória e narrativas de idosos}

A história oral é instrumento metodológico enriquecedor, pois vozes múltiplas se encontram socialmente, constituindo um campo de memórias diversificadas, cujo debate fortalece a experiência social de aprender aquilo que se desconhece por quem tem um tesouro: as recordaçóes. Em uma região amazônica rural, como o Mocambo do Arari, o recurso da história oral dialoga com a condiçáo de escassez de documentos escritos, ao mesmo tempo, tem se revelado fundamental para a compreensão, no âmbito da cultura, dos processos de reconstituição de experiências de resistências e de lutas cotidianas por meio da memória individual, que também é uma memória social (Portelli, 1997a).

Desse modo, a história oral, como recurso metodológico, possibilitou ouvir idosos pobres, moradores de comunidades rurais amazônicas, como o Mocambo do Arari, Parintins. Essas mesmas pessoas, subalternizadas, geralmente com pouca alfabetizaçáo, permanecem no campo da ocultação da memória, invisibilizadas, negadas, mas renitentes, resistentes. Do contrário, "ao privilegiar a análise dos excluídos, dos marginalizados e das minorias, a história oral ressaltou a importância de pensar em uma memória subterrânea que, como parte integrante das culturas minoritárias e dominadas, se opóem à 'Memória oficial'” (Pollak, 1989, p. 4). Isto é, permitiu "o registro e análise das memórias dos sujeitos sociais, possibilitando o estudo acadêmico a partir de pontos de vistas desses atores sociais" (Silva; Torres, 2019, p. 83).

Ao pensar a questão da memória, Pollak (1992) escreve que ela é constituída por pessoas, personagens em diálogo com os lugares de memória, por intermédio do ato de rememorar. Assim, são sujeitos históricos, que reconstroem o passado e o reinterpretam, atores sociais de diversificadas memórias, que destacam em suas trajetórias individuais, de vivências em diferentes tempos, experiências sociais diversas.

Ao tecer relaçôes sobre memória, Bosi (1994) escreve sobre a legitimidade de idosos para o debate histórico, cujas narrativas falam o melhor de si mesmos, pois, muitas vezes, pessoas idosas vivem uma vida solitária, quando em muitos casos já esperam a hora da partida. Neste sentido, embora as narrativas que pude colher sejam de suas histórias pessoais (valores morais e sociais), elas dialogam com os outros que também participaram desses momentos: os companheiros de trabalho no campo, os vizinhos e os amigos da igreja. Portanto, a memória ultrapassa a ideia de individual e se torna social. Importante comentar que, embora muitos narradores tenham esquecido determinadas datas e momentos, ou falhas de cronologia, faz parte do ato de rememoração esquecer ou confundir, uma vez que "uns e outros sofrem processos de desfiguração, pois a memória grupal é feita de memórias individuais” (Bosi, 1994, p. 419). Assim sendo, a reconstrução da memória passa por caminhos múltiplos enquanto vivenciada pelos idosos.

Tomelin Jr (2013), ao refletir sobre as experiências de pessoas idosas em situação 
de internaçáo psíquica, considerou ser importante as narrativas orais dos velhos para o debate histórico, pois se trata de um campo de investigação e intepretação sobre a realidade social da velhice e a invenção de seus modos de vida como luta; tais questóes se explicam por valores, sentimentos, sociabilidades e presença de agentes reais, sujeitos históricos da sociedade. Em conformidade com a leitura do autor, no Mocambo do Arari, os idosos relatam seu passado associando-o a sua juventude, destacando a vitalidade para as brincadeiras do lugar e as dificuldades ocasionadas pelo envelhecimento. Sáo esses mesmos sujeitos históricos, como últimos vestígios da sociedade, que possuem memórias associadas à cultura - os cordóes de pássaros -, cujos discursos dimensionam as práticas políticas e sociais da experiência, de sujeitos produtores e produtos do real, que ultrapassam os modos de vida e constituem um caminho da história pela sua presença, resistência, esperanças, utopias, tristezas e lutas individuais em suas práticas sociais.

$\mathrm{Na}$ oportunidade de conversar sobre sua trajetória de vida organizando o pássaro Jaçaná, seu Milton Almeida, a princípio, demonstrou resistência, pois, segundo ele, havia outras pessoas que poderiam falar sobre a brincadeira. Assim sendo, conforme ensinou Bosi (1994), era necessário estabelecer uma relação de confiança mútua. Com um pouco mais de conversa, procurei ganhar a amizade do narrador, falando sobre assuntos do dia a dia, esperando o momento adequado para que se sentisse à vontade parar abrir seu coração, pois "quando os dois passam a se conhecer melhor, a 'vigilância' do narrador pode ser atenuada" (Portelli, 1997a, 36).

Neste sentido, acredito que a escolha do lugar para a entrevista foi fundamental: a casa do narrador. Conforme ensinou Toutier-Bonazzi (2006), o local escolhido deve ser um ambiente em que o narrador se sinta à vontade e receba melhor o pesquisador. Além disso, o ambiente do lar oferece condiçóes para se pensar o cotidiano e a personalidade do narrador, bem como, eventualmente, propicia o exercício de recordar, avivar as lembranças por meio de fotografias, cartas e documentos. Por se tratar de uma pessoa com idade avançada, acometida de uma enfermidade, o encontro com o narrador não pôde se estender por muito tempo. Também tive o cuidado com determinadas perguntas excessivamente meticulosas, no intuito de náo "acontecer que, decepcionada por não poder responder, a testemunha se perturbe e interrompa ou abrevie a entrevista" (Tourtier-Bonazzi, 2006, p. 233). Seguindo a leitura da autora, mostrei-me paciente para ouvir, respeitando o andamento das recordaçóes e o vir à tona delas em momentos diferentes, isto é, sem necessariamente seguir uma cronologia, construindo uma relaçáo de confiança entre o narrador e o entrevistador para que o diálogo se tornasse mais intimista.

O roteiro das entrevistas seguiu a proposta de começar a conhecer a história de vida do narrador, perguntado sobre a infância, a juventude, o trabalho, as relaçóes familiares, mediante também uma consulta prévia sobre assuntos de sua vida. Contudo, mesmo não renunciando a determinadas perguntas, foi importante deixá-lo parcialmente livre, permitindo a sua espontaneidade, pois "se a entrevista for bem encaminhada, chegará 
um momento em que as perguntas não serão necessárias; a testemunha, mergulhada em seu passado, se sentirá perfeitamente à vontade e, esquecendo a presença do microfone e do entrevistador, dará largas às recordaçôes" (Tourtier-Bonazzi, 2006, p. 237).

Após esse procedimento, as transcriçóes foram realizadas por mim, por acreditar na possibilidade de tornar o texto mais claro, pois "o resultado final da entrevista é o produto de ambos, narrador e pesquisador” (Portelli, 1997a, p. 36). Neste sentido, a afinidade entre pesquisador e narrador foi importante na construçáo de um relacionamento mútuo, com foco na subjetividade do segundo, na medida em que os dados são extraídos da entrevista. Assim, os depoimentos e as lembranças revelaram fatos e significados importantes no campo da revalorização de experiências e outras memórias de seu Milton Almeida, em sua trajetória brincando e organizando o pássaro Jaçanã por mais de meio século.

\section{Contextualizando os "pássaros" da Amazônia}

Tema relativamente pouco visualizado na historiografia amazônica, os cordóes de pássaros e bichos foram tratados por alguns pesquisadores, com destaque para os estudos de Moura (1997), em O teatro que povo cria: cordóes de bichos e pássaros juninos, cuja obra narra sobre a temática, a formaçáo da festa, o enredo que a envolve e as histórias dos donos dos pássaros para manter a cultura paraense.

Salles (1994) narra a existência dos pássaros desde a segunda metade do século XIX, quando estes se associaram ao boi-bumbá em forma de teatro popular, originados a partir dos antigos cordóes de bichos - brincadeiras recorrentes no interior do estado do Pará, que se apresentavam no Largo de Nazaré, na capital. Charone (2009) faz alusão a como se estruturou o cordão de bichos e pássaros na cidade de Belém que, ao assimilar elementos da cultura local, fez surgir outra modalidade da cultura paraense: o pássaro Junino, ${ }^{6}$ denominado como "ópera cabocla”.

Para Carneiro (1980, p. 223), trata-se de "uma alegoria popular, que resulta numa defesa da flora, e da fauna da regiáo norte”. Loureiro (2001) disserta que as festas dos pássaros são genuinamente paraenses, resultantes das experiências dos encontros de negros, indígenas e brancos na Amazônia. Em conformidade com o que Salles (1994) e Figueiredo e Tavares (2006) escrevem, a cidade de Belém do Pará abriga diversos grupos

6 Os cordões de bichos e pássaros são comumente encontrados no interior do estado do Pará, cujas apresentações encenam agonia, morte e ressurreição do animal, performance que ocorre em forma de meia lua, daí o nome cordão. Nesta modalidade, o personagem principal entra e permanece em cena. A outra variação, conhecida por pássaro Junino, mais presente na capital, tem por particularidade a encenação de caráter teatral, com drama, cenário, iluminação, falas e ensaios, cujos personagens saem e entram em cena em momentos específicos, no abrir e fechar das cortinas, embora preserve a narrativa de morte e ressurreição do patrono do folguedo (Moura, 1997; Figueiredo; Tavares, 2006). 
de pássaros, cuja origem está relacionada ao boi-bumbá e aos teatros populares e que os nomes dos grupos folclóricos são oriundos de um bicho - daí o termo cordões de bichos -, que se apresentam todos os anos no período junino.

Sendo assim, é possível entender que os cordóes de bichos e pássaros são criados com referência à fauna da regiáo e associados à experiência cotidiana das classes populares, por isso dançados nas ruas da cidade, a exemplo do que acontece com o carnaval de rua. Nessa perspectiva, Loureiro (2001) propóe que, em todas as formas, a condição de arte popular emerge, pois nasce do povo e para o povo, por meio de recursos dramáticos que o teatro apresenta com grande complexidade cênica.

Moura (1997) observa a presença de cordóes de bichos e pássaros na Amazônia com referências à realidade regional, pois, geralmente, o animal caçado era o patrono do cordão, representado por meninas que se utilizavam de danças alusivas ao animal ao fazerem uso de máscaras, conforme narrou o autor.

As danças miméticas dos porta-pássaros, graciosas meninas impúberes que 'portam', isto é, carregam o animal patrono do cordão, pode-se perceber um tenuíssimo fio que as ligam às danças imitativas relativas a animais e que ocorrem na Amazônia, tais como a dança do Camaleão, do Jacaré, do Gambá, do Bagre, do Macaco, do Peru e do Jacundá. (Moura, 1997, p. 69).

O autor ainda menciona que no interior do Pará também é registrada a presença dessas festas entre os anos 1901 e 1990, chegando ao número de 185 grupos de pássaros - precisamente, cordóes de pássaros, cordões de bichos, cordóes de seres lendários e cordóes não identificados - que existiram em Belém e no interior do estado do Pará em diferentes tempos e durações (Moura, 1997).

Ao procurar evidências sobre a criação e organização dos pássaros, encontrei na obra de Moura (1997) a forte presença negra, evidenciada pela religiosidade de matrizes africanas expressa na assistência espiritual durante as apresentaçóes dos pássaros na cidade de Belém, provavelmente pelo fato de que a maioria dos cordóes de pássaros e pássaros juninos é de propriedade de mães/pais de santo. Chamado de "cena de macumba" pelo autor, a pajelança feita para ressuscitar o pássaro consiste em invocar os encantados (mestres ou guias), usar ervas e o cigarro tauari para defumar o animal de modo que retorne à vida, ${ }^{7}$ conforme observou:

Durante a apresentação do cordão de pássaros tem-tem, por ocasião do festival Junino/1990, o proprietário e pai de Santo João Guapindaia, presente em cena o tempo todo, colocou-se discretamente à coxia, na esquerda baixa do palco, onde entoava doutrinas, durante a cena da macumba. (Moura, 1997, p. 212).

Segundo os autores Maués e Villacorta (2011), a pajelança amazônica pode ser entendida como um conjunto de práticas religiosas no combate às enfermidades sob a orientação dos encantados (mestres, 
A citação acima reforça a presença negra na organização e participação temática, importante e direta na apresentação dos pássaros. Ainda, Moura (1997) observa que tal cena é levada táo a sério pela personagem feiticeira - representada por uma mãe de santo - que muitas pessoas na plateia incorporam entidades e manifestam-se no exato momento de cura do pássaro.

Na encenaçáo do Guará do Lago Encantado, Menezes (1993, p. 245) já observara que, durante a performance do curador do pássaro, uma cantiga era usada para invocar entidades durante o rito para desencantar o animal: "Meu mestre Pena Amarela/ Meu Santo, meu Orixá/ Vamos fazer um "trabalho" / Pra desencantar o Guará".

Soma-se aí o estudo de Andrade (1978), no qual discorre sobre as festas dos pássaros no Amazonas, em cujas encenaçôes é possível verificar a presença negra, inclusive no que se refere às origens das brincadeiras. Segundo o autor, a guardiã do "Japiim", do bairro da Praça 14 de Janeiro, dona Inês Silva, lhe contou que organizou o pássaro de 1930 até a última vez que brincou nas ruas da cidade de Manaus, em 1968, mas que a brincadeira foi trazida de Belém por um africano chamado Elias. Importante ressaltar que, no bairro onde brincou o pássaro, está localizado o Quilombo de São Benedito, reconhecido por ocasião da centenária festa do santo e certificado pela Fundação Palmares, em 2014 (Silva, 2011).

Desde a década de 1920, registra-se a presença de cordôes de bichos e pássaros nas ruas da cidade de Manaus, em comemoração aos santos da época junina.

Os bois eram parte dos folguedos, mas as danças de roda, as cirandas, as quadrilhas, as adivinhaçôes, os cordôes de bichos e os 'pássaros' ('japiim', 'tucano', 'bem-te-vi', 'gavião', 'corrupião', 'guará') eram o forte desde o início do século. Bairros, como a Cachoeirinha, eram famosos por seus arraiais na época junina. (Costa, 2002, p. 148).

Ainda no Amazonas, na cidade de Parintins, existiram vários pássaros, como o "Surucuá" (Assayag, 1997, p. 42). Em seu livro O magnifico folclore de Parintins, Saunier (1989, p. 29) faz referência à existência dos cordôes de bichos e pássaros entre as décadas de 1930 e 1960, que dançavam nas residências ou à frente delas e andavam pelas ruas deleitando o povo: "[...] do Uaicurapá veio o cordáo de tambaqui (peixe de carne saborosa do Amazonas) que era conduzido espetado na ponta de uma flecha, por uma menina vestindo roupas coloridas. Os personagens eram o Padre, o Amo, pajé, pescador e índios". O mesmo autor ainda menciona que, na década de 1940, "os cordóes de pássaros na época eram Rouxinol do Florival Telegrafista, o Benteví e a Gaivota do Venâncio e o Guará do Sr. Justiniano Seixas" (Saunier, 1989, p. 29).

Em síntese, os cordôes de pássaros narram a história de um pássaro de estimação

guias e caboclos), com uso de ervas, rezas, defumações e fé. Para distingui-la do xamanismo, os autores a denominam "pajelança cabocla". 
que ao ser morto por um caçador deixa seu dono entristecido a ponto de pedir ajuda de um pajé/curandeiro para ressuscitá-lo, momento este que mantém relação próxima com o auto do boi-bumbá de Parintins, o qual se originou com base nas manifestaçóes do bumba meu boi.

Segundo Braga (2002), os cordóes de bichos e pássaros se apresentavam em Parintins junto às quadrilhas e aos bumbás Garantido e Caprichoso. Preservados ainda na zona rural, os pássaros Jaçanã e Pavão Misterioso se apresentam em disputa pelo título do Festival Folclórico do Mocambo do Arari. Em comum com os bumbás parintinenses, a "promessa de santo", observada na história dos pássaros.

A presidente atual do Grupo Folclórico Pavão Misterioso, Maria América Almeida Teixeira, em conversa informal: 'foi promessa a São João Batista, feita pela antiga dona do pássaro, Laíde Bezerra, para se curar de uma doença e, se alcançasse as graças, colocaria todos os anos a brincadeira'. A festa é apresentada em julho [...]. (Silva; Lima Júnior; Mascarenhas, 2019, p. 95).

Neste sentido, o pássaro Pavão Misterioso, fundado em 1977, na comunidade Lago da Esperança, passou a ser conhecido como o "cordão da promessa”. O pássaro Jaçaná aparece no Mocambo do Arari com a chegada dos irmáos Messias, do município de Maués (AM), que brincavam com o pássaro nas horas de lazer, após longa jornada de trabalho na juta, em 1952. Após o retorno desses trabalhadores para o município de origem, coube ao senhor Milton Almeida a continuidade da festa, pois ele sabia fazer a brincadeira (Gomes, 2017).

\section{"Só era o Jaçanã no tempo das fogueiras": memórias de luta e solidariedade}

Nascido no Lago do Boiador, ${ }^{8}$ Milton Teixeira Almeida9 se mudou para o Mocambo do Arari para trabalhar na juta, no início da década de 1950. Na oportunidade em que o conheci, seu Mimi, como é carinhosamente chamado, contava 83 anos de idade e tinha algumas limitaçóes físicas devido a uma doença na perna, que dificultava a sua locomoção. Uma história de quem conheceu a necessidade/imposição de implicar a resistência de seu próprio corpo nas atividades que exerceu no campo. Trabalhador,

8 Um lago de várzea localizado no outro lado do rio Amazonas. Conforme Silva (2009), muitas pessoas foram para o Mocambo do Arari refugiando-se das grandes enchentes.

9 Com base nas questões propostas pela história oral, mantive o nome original do narrador, bem como a narrativa em seu estilo próprio, sem as ditas “correções” gramaticais ou quaisquer intervenções no texto transcrito, preservando a oralidade, percepções, costumes e saberes. 
seu Mimi exerceu atividades no roçado de mandioca, milho, no cultivo da juta, no pescado e também tirando lenha pra vender. ${ }^{10}$ Isto é, são experiências conjugadas com atividades diversas e combinadas desses trabalhadores, cujo "espaço, onde esse conjunto de diferentes sujeitos vive, é carregado de simbologias, contradiçôes, vozes, solidão, vivacidade, tristezas e esperanças" (Albuquerque, 2005, p. 35).

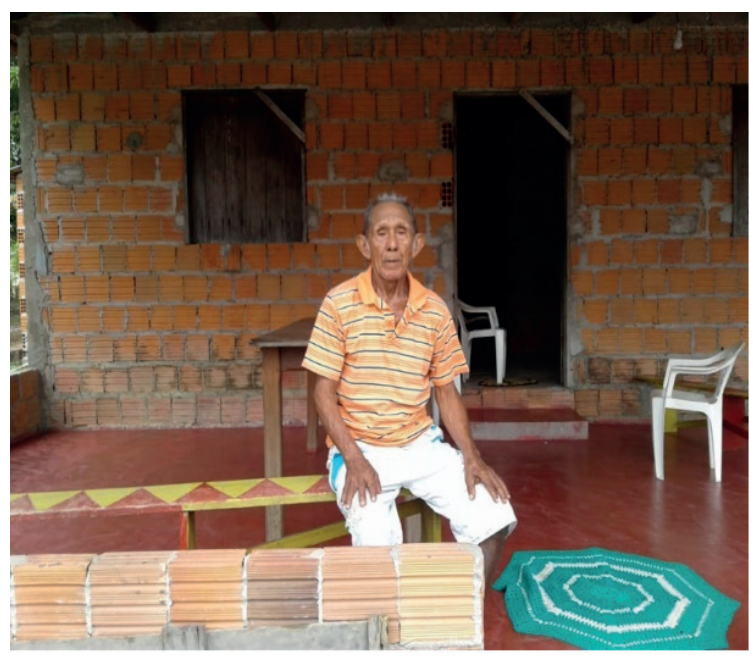

Imagem 1- Milton Almeida em sua casa na agrovila do Mocambo do Arari, Parintins (AM), 2017. Fonte: acervo do autor.

$\mathrm{Na}$ fotografia de seu Milton, de imediato, notam-se as cores vermelho e amarelo do seu pássaro, cuidadosamente retratadas na pintura no banco de sua varanda, onde passa boa parte da tarde, registro do momento em que pudemos nos encontrar e conversar. Destaca-se, sobretudo, a altivez do olhar desse morador do Mocambo, que aposta em seu próprio lugar, história, saberes e lutas. A fotografia do narrador, como as demais apresentadas no texto, permite visualizar aqueles que historicamente estáo escondidos, mas que sob as lentes saem do campo da ocultação e ganham protagonismo (Benjamin, 1985).

As referências narrativas de seu Milton alargam entendimentos sobre as formas de organização e articulaçấo acerca de suas vivências na organização da festa do Jaçaná, das dificuldades impostas pela ausência de alguns direitos, entre eles, a possibilidade de estudar, que era remota na regiáo, pois era necessário remar pelo rio Amazonas para alcançar locais que tivessem escola e professores; tal situação era conjugada com a necessidade de trabalhar no campo e no pescado, ainda criança. Desse modo, não avançou nos estudos, parando na quarta série do primário.

Quando eu conheci o Mocambo, era isolado. Água tinha bem pouco. Não tinha 
luz. A gente vivia numa escuridáo, sendo alumiado com a lamparina e o querosene. A água, a gente bebia essa mesma. Era preciso passar um pano pra tirar toda a sujeira que tinha. Escola que não tinha mesmo. Eu estudei, mas não foi demorado. Cheguei a estudar um ano na cabeceira do Mocambo. O resto do meu estudo foi polpa da canoa, com meu livro e um lápis, um caderno escrevendo e ajudando o meu pai a pescar por aí. Foi como eu aprendi a assinar meu nome completo. Agora, a educaçáo melhorou. Fede [tem muito] professor nesse Mocambo. (Milton Teixeira Almeida, 2017).

As narrativas entre passado e presente, tomando por base o fio da memória, ressignificada pelo narrador, destacam dimensóes históricas de exclusôes, minimizadas com as recentes políticas educacionais, de água e eletricidade adotadas no país pelos governos Lula (2003-2010) e Dilma (2011-2016). Neste sentido, o uso da história oral como ciência e arte do indivíduo se mostra primordial, pois "embora diga respeito a padróes culturais, estruturas sociais e processos históricos, visa aprofundá-los, em essência, por meio de conversas com pessoas sobre a experiência e as memórias individuais e ainda por meio do impacto que elas tiveram na vida de cada uma" (Portelli, 1997b, p. 15).

Casado com dona Ilarina e pai de sete filhos, é reconhecido por ser um dos primeiros moradores, além de presidente da comunidade, contribuindo para amenizar as dificuldades comuns a esses espaços, onde os moradores se organizam e tomam à frente de serviços que deveriam ser de responsabilidade do poder público.

Graças a Deus, eu sou um dos fundadores. Eu com minha mulher. E acho que desses fundadores só existe eu e ela. Resto todo já morreram. Naquele tempo nem existia casa. Eu tenho saudades do Mocambo. Minha vontade é morrer na comunidade, porque eu foi um dos fundadores da comunidade, ajudando abrir as ruas dum fim ao outro na época da Congregação Mariana. Eu fui um dos guerreiros da comunidade, porque naquele tempo nós roçava na capoeira. Não era brincadeira, não! (Milton Teixeira Almeida, 2017).

Ao recordar de sua juventude, reconstrói o passado destacando a vitalidade proporcionada por ela, em contradiçáo ao envelhecimento e à morte de amigos, vizinhos e parentes, pessoas de seu tempo que partiram, como se a sua vez estivesse chegando, pois, a "própria vida social se encarrega de mostrar ao velho a proximidade da morte" (Barreto, 1992, 34).

Acho que todo cristáo tem saudade da época quando era solteiro, novo. Era pra trabalho, pra festa. Quando a pessoa é nova tem vontade pra tudo. Agora quando é velho acaba com tudo. Até com 50 anos eu trabalhava, depois de 60 já foi baixando as forças, daí que eu parei de trabalhar. (Milton Teixeira Almeida, 2017). 
A narrativa de seu Milton revaloriza perspectivas de experiência de trabalho no campo e o processo de envelhecimento, observando atividades pesadas, que ameaçam a saúde e, por fim, outras possibilidades de enfrentar o tempo futuro. Constata-se ainda a articulação do trabalho produtivo com o tempo da juventude, relacionando nesse campo de memórias que denotam valores morais de um bom trabalhador, bem como reflete sobre a impossibilidade de desenvolver plenamente seus momentos de lazer devido à idade avançada.

As memórias sobre o cordão de pássaro Jaçanã têm forte ligação com a história de vida de seu Milton, pois foi ele quem retomou a brincadeira em 1956, quando os irmãos Messias, trabalhadores da juta, que haviam levado o pássaro para o Mocambo, retornaram para Maués (AM), conforme dito anteriormente. Desde entáo, organizou e lutou juntamente com outros companheiros para que a brincadeira continuasse.

Essa brincadeira é muito velha aqui. O Jaçanã é de 52, quando um pessoal de Maués trouxeram. Ele veio de Maués. O pessoal que veio pra trabalhar na juta. Eu era brincante do cordão, eu brincava de índio. Eles que eram o dono. Eu só brincava. Depois parou, aí depois de um tempo a gente botou e o ficou pro pessoal daqui. Ele já tinha esse nome quando brincou aqui, mas deve ser porque ele é fácil [de encontrar] por aí, por essas beirada. (Milton Teixeira Almeida, 2017).

Quando a Congregação Mariana formalizou a comunidade de São João do Mocambo do Arari, em 1964, a brincadeira do pássaro passou a acontecer nos festejos do santo, possibilitando momentos importantes de sociabilidade entre os comunitários, até entáo, encontrando receptividade por parte dos religiosos, uma vez que não havia bebidas alcóolicas, conforme menciona.

O Jaçanã entrou na festa do São Joáo pra animar mais a festa, o pessoal que estava aí, porque se fosse só na fogueira não tava animado. Era só a juventude que dançava mesmo, não tinha bebida nenhuma naquele tempo. Os padre gostaram, acharam animado, o padre Augusto, o outro padre, também. Tudo eles gostaram. Eu queria continuar a festa dentro da igreja, que o Jaçanã é do São João. Esse é o meu sonho. (Milton Teixeira Almeida, 2017).

Em diálogo com Tomelin Jr (2013), em que o autor analisa as experiências de Eulina, uma idosa em estado de internação psiquiátrica em São Paulo, compreendese que a memória é uma prática em movimento em que se constrói lembranças e expectativas de reviver alegrias, encontros e amizades, semelhante ao que se nota nas narrativas de Milton, cujas experiências sociais falam de um passado de vivências agradáveis, articulando um amanhã com soluçôes.

As narrativas de seu Milton tratam da importância da festa do pássaro em sua história de vida como agente social da brincadeira e suas expectativas e frustraçóes 
diante das mudanças ocorridas na própria festa, pois, para ele, a brincadeira deveria continuar nas festividades de São João. Importante mencionar que após os ritos religiosos, começavam a festa do pássaro, com danças, músicas, comidas e bebidas, isto é, uma forma de transgredir o cotidiano sério imposto pela cultura oficial (Bakhtin, 1999).

Turner (2015), ao analisar a "antropologia da performance" como parte essencial da "antropologia da experiência" (a experiência vivida), destaca que tanto o trabalho quanto a brincadeira (atuar) para as sociedades ocidentais (euro-americanas) possuem caráter energético e conflituoso, uma vez que o "contido" se revela. O autor escreve sobre a compreensão da condiçáo humana representada no palco, performance em que os sentimentos são dimensionados mais intensamente que no cotidiano: as experiências passadas são revividas e evocadas, articulando com o presente. Assim sendo, "representar, portanto, é trabalho e lazer, solene e lúdico, presunção de sinceridade, nosso tráfego e comércio mundanos e o que fazemos ou assistimos nos rituais ou no teatro" (Turner, 2015 , p. 145). Isto posto, as formas expressivas de festas, danças e teatros suscitam implicaçóes quando rompem com o fluxo cotidiano.

Guarinello (2001) disserta que festa é um ponto de confluência das açôes sociais, nas quais os participantes se encontram em torno de um objeto celebrado. Desse modo, implica a concentraçáo de afetos e emoçóes, produzindo determinada identidade no tempo e nos espaços sociais entre aqueles que participam. Contudo, o autor problematiza questôes referentes à produção de identidade por meio das festas.

Por outro lado, dizer que a festa produz identidade não significa afirmar que produza, necessariamente um consenso, muito pelo contrário. A festa é produto da realidade social, e como tal, expressa ativamente a realidade, seus conflitos, suas tensóes, suas cesuras, ao mesmo tempo que atua sobre eles. (Guarinello, 2001, p. 972).

Acerca da citação acima, o autor ressalta que não entende a festa como inversão ou subversão social, ou seja, considera a festa como um espaço com regras bem definidas, códigos de conduta e expectativas recíprocas. Assim sendo, para Guarinello (2001, p. 973), a festa é "um espaço aberto no viver social para a reiteração, produção e negociação de identidades”. Em outras palavras, a festa não apaga as diferenças, ao contrário, as une. Conforme analisou o autor, não se trata de uma identidade criada de forma homogênea, tampouco uniforme, pois a festa pode ser lida de diferentes formas pelos participantes, isto é, é repleta de significados. A festa é, portanto, uma produção do cotidiano, uma ação coletiva de interrupção do tempo social, ao suspender atividades diárias.

Em Nasci nas matas, nunca tive Senhor, pesquisa sobre o quilombo Pacoval, em Alenquer (PA), Funes (1996) observa que a religiosidade católica é muito forte nas comunidades rurais, a exemplo dos mocambos, sendo a única religião permitida e praticada. Assim, as festas de santo faziam parte da vida dos quilombolas - momentos 
de fé e lazer -, oportunidade em que namoravam e bebiam, isto é, era quando o sagrado e o profano se confundiam. Neste sentido, a busca pelo direito à terra está relacionada em uma dimensão maior da vivência dos escravizados. Os momentos de lazer para os escravos eram também de subversão à ordem escravista. As festas eram ocasiōes em que os negros se afirmavam enquanto identidade e resistência à escravidão, no que se refere ao hibridismo cultural, constituindo novas identidades, pois "a festa religiosa inseria na malha fina da escravidão, abertura para os pretos exercitarem sua capacidade organizativa. Dava oportunidade à maior interação social entre pretos livres e escravos" (Bandeira, 1988, p. 130).

Em narrativa semelhante à leitura de Funes e Bandeira, menciona seu Milton sobre o processo de construção da memória do Mocambo e da organização dos trabalhadores locais para a realização da brincadeira do pássaro Jaçaná.

Não existia brincadeira nenhuma. Só era Jaçanã no tempo das fogueiras. Só no mês de junho. Só era nas ruas. Onde tinha fogueira a gente parava e brincava. Parava de trabalhar, formava o pássaro, a brincadeira. Não tinha diversão. E brincava no cordáo que eu sabia. E pra nós fazer uma festa mais animada um pouco, eu consegui levar o Jaçanã pra frente, né, brincando com as criança, com as menina, que não tinha muita gente mesmo, né. Eu fazia convidando meus companheiro, que era da comunidade, pra nós trabalhar, arrumar dinheiro pra poder a gente realizar a festa, porque naquele tempo não tinha patrão pra dar pra nós. Era o nosso trabalho mesmo, era nós reunir os homens, os chefe de família, fazer um puxirum, poder ganhar dinheiro, pra poder a gente realizar a festa. (Milton Teixeira Almeida, 2017).

Milton narra sobre as estratégias criadas por ele para fazer a brincadeira do pássaro no Mocambo, entre as quais, a convocação das crianças para brincar, incluindo suas próprias filhas e também os companheiros de trabalho, vizinhos e amigos, aproveitando o pouco tempo disponível que dispunham para fazer a festa do pássaro, pois representava uma das poucas ocasióes de lazer, importante momento que "não é tomado [...] como dimensão temática isolada de outras da vida social e cotidiana" (Sossai; Coelho, 2014, p. 12). Isto é, trata-se de um processo humano carregado de significados.

O caráter solidário é verbalizado com o termo puxirum - experiência do trabalho coletivo comumente encontrada na história de vida de trabalhadores e trabalhadoras do campo -, cuja atividade reúne um grupo de mulheres e homens para fazer em poucos dias o roçado e a plantação. Em uma das mais antigas referências, Eduardo Galvão, em Santos e visagens, contribui para o entendimento do trabalho cooperativo nas roças, denominado por ele de "puxiróes", prática em que o "roceiro convida as famílias vizinhas para ajudá-lo, [...] traço que induz maior solidariedade” (Galvão, 1976, p. 27).

Em conformidade, Candido (2003) disserta que o puxirum, ou melhor, o "mutirão", é a denominação dada para o trabalho coletivo, também como eventual 
obrigação para com Deus, incluindo laços de vizinhança, em que os convocados não costumam se negar. Isto é, experiências compartilhadas na organização e ajuda mútua. Experiências de sujeitos históricos, trabalhadores do campo, que pluralizam articulaçóes de coletividade em prol de um objetivo, conforme registra a imagem abaixo, onde é possível ver a presença de seu Mimi nessa prática social.

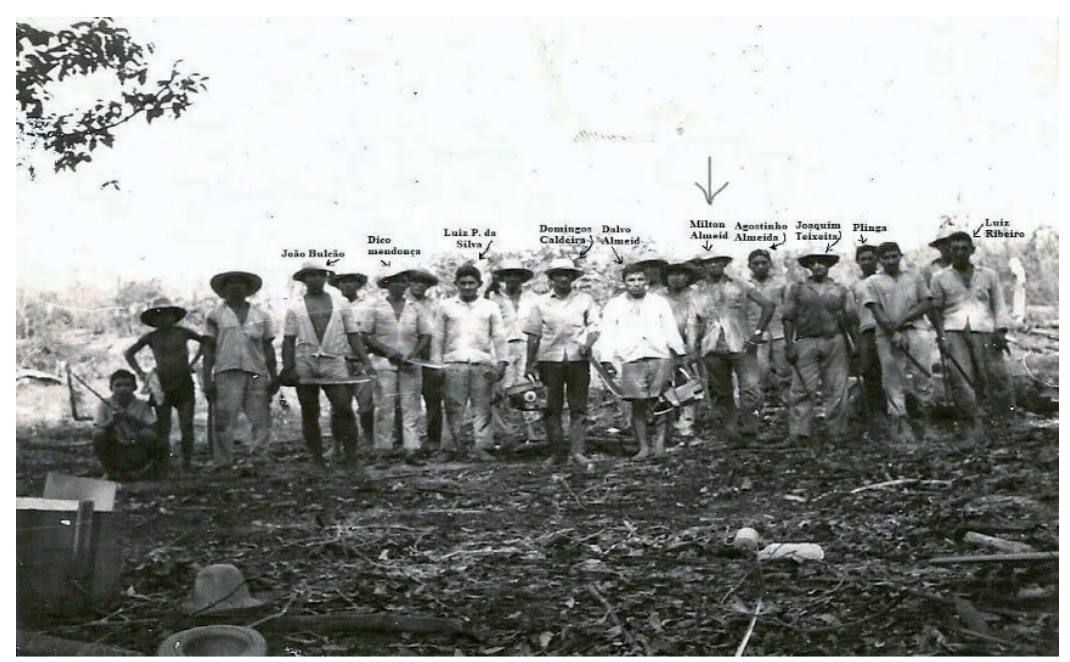

Imagem 2 - Milton Almeida e outros trabalhadores do Mocambo organizados em puxirum no Mocambo do Arari, 1980. Fonte: acervo pessoal de Francisco Geraldo Caldeira.

Candido (2003, p. 88) acentua, no entanto, que o puxirum não se resume ao trabalho na roça, mas a uma articulaçáo de vizinhos por meio da solidariedade: "derrubada, roçado, plantio, limpa, colheita, malhação, construção de casa, fiaçáo, etc.". Contudo, "não há remuneração direta de espécie alguma, a não ser a obrigação moral em que fica o beneficiário de corresponder aos chamados eventuais dos que o auxiliaram".

Em conformidade, Medeiros (2015) compreende o trabalho coletivo como atividade em que todos da comunidade se reúnem numa data previamente combinada para fazer o trabalho na terra de determinada pessoa. Acrescenta ainda os aspectos do puxirum para outros fins: "limpar o terreno do centro comunitário, para construir a igreja ou a escola, geralmente com o dinheiro conseguido na festa da comunidade" (Medeiros, 2015, p. 62).

Entre outras formas para a realização da festa do pássaro, seu Milton Almeida buscou variadas maneiras de angariar recursos. Na década de 1970, por exemplo, ele criou um time de futebol, organizou um campeonato na comunidade do Mocambo e chamou alguns vizinhos e amigos para participarem da sua equipe, buscando com 
a vitória no campeonato obter recursos para a realização da brincadeira do Jaçaná. Os moradores, então, se reuniram em puxirum para fazer um campo de futebol. Assim, seu Milton e os demais moradores articularam momentos de sociabilidade por meio da organização do campeonato de futebol e também tecendo relaçóes de solidariedade para manter a festa do pássaro na comunidade.

Neste sentido, entendo que as experiências históricas, vivenciadas por meio da cultura, promovem o convívio social entre sujeitos sociais, cujas dimensóes de luta se dão em virtude das manifestações festivas como estratégia de resistência à ordem vigente, pelo direito à memória e também "sobre como o envelhecimento é relacionado com a construção de novos laços sociais" (Sossai; Coelho, 2014, p. 11).

Os dois pássaros se apresentavam tradicionalmente na festa de São João, padroeiro local. Entretanto, importante registro disserta que em 1994 os pássaros e os bois foram impedidos pelo pároco da igreja de dar continuidade as suas apresentaçóes nos festejos de São João Batista, pois os elementos anímicos, crenças, valores e os tambores que as brincadeiras apresentavam eram considerados profanos pela Igreja Católica (Gomes, 2017). Talvez se possa começar a perceber esses valores afros pela própria escolha do pássaro como elemento anímico: "E o pássaro que usamos como símbolo tem a ver com a tradição nagô, segundo a qual a ancestralidade feminina é representada por pássaros [...]” (Gonzalez, 1994, p. 182).

Em 2004, foi criado o Festival Folclórico do Mocambo do Arari, resultado das experiências históricas de lutas e resistências de mulheres e homens face às exclusões que as brincadeiras sofreram por parte da Igreja Católica, demonstrando as perseguiçóes às manifestaçóes culturais que de alguma forma fogem ao padrão cristão instaurado pelo eurocentrismo, ou seja, repressóes e tentativas de unificar as diversidades culturais. Contudo, os pássaros foram secundarizados pelos bois-bumbás da localidade que, ao tomarem como modelo as consagradas apresentaçóes dos bois Caprichoso e Garantido, conquistaram os moradores mais jovens. Portanto, tornaram-se as principais atrações do evento - com mais visibilidade, divulgação e transmissão. Por consequência, recebem maior apoio financeiro da prefeitura de Parintins, custando cada vez mais a perda de interesse dos mais jovens pelos pássaros (Gomes, 2017).

Outra vez, a manutenção da festa dependeu da articulação dos moradores, isto é, dos mais antigos. "Pelo que participei das noitadas do festival, as brincadeiras dos pássaros foram mais animadas que do boi. Pelo menos, eu vendo o pessoal que vieram de Parintins, eu vi que se manifestaram mais no Jaçaná que nos bois, que já tem em Parintins" (Milton Teixeira Almeida, 2017). Contudo, seu Milton não pôde mais continuar assumindo o comando do pássaro: "eu fiquei velho e adoeci na minha perna. Isso me impediu de continuar trabalhando diretamente como eu trabalhava no Jaçaná. Agora o pássaro tá com a Edneia. Ela que toma conta agora" (Milton Teixeira Almeida, 2017). Dito de outra forma, a enfermidade foi/é um obstáculo para o desenvolvimento de saberes e fazeres de seu Mimi no comando da festa do pássaro, sendo sucedido, em 
2013, por seus familiares. Atualmente, a agremiaçáo cultural é presidida por sua filha, Edneia Almeida, 44 anos, que, orientada pelo pai, vai de casa em casa convidando os moradores para os ensaios do pássaro, em preparação para o dia da apresentaçáo no festival do Mocambo do Arari - uma estratégia de reivindicação por direito à festa.

O protagonismo de seu Milton na comunidade é destacado em uma quadra poliesportiva que recebe o seu nome, também é evocado por meio da festa, evidenciado, por exemplo, no momento de apariçáo do guardiáo do pássaro, celebrado com uma música que pude colher quando assisti à apresentação do Jaçanã: "Nossa cultura e nossa tradição/Nossos artistas são todos de São João/ Agradecemos o senhor Milton Almeida/ Com a sua inteligência criou o nosso Jaçanâ”.

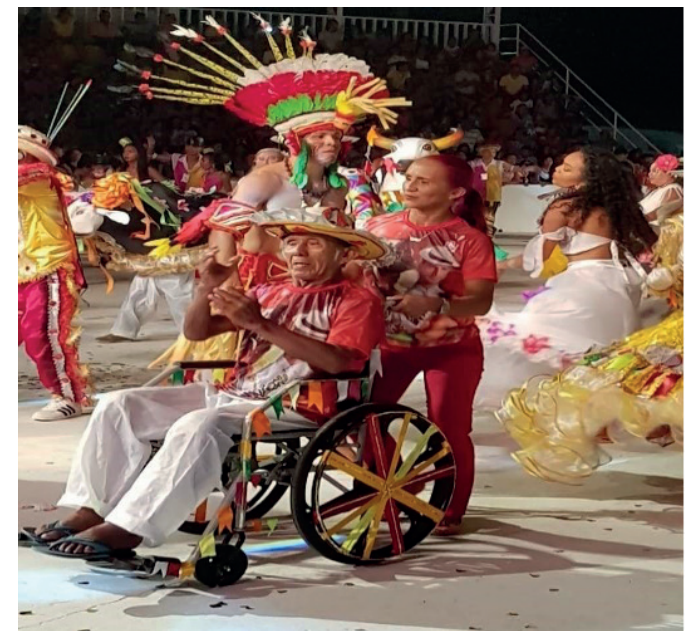

Imagem 3 - Milton Almeida brincando no pássaro Jaçanã, conduzido por sua filha Edneia, durante o Festival Folclórico do Mocambo do Arari, 2018.

Fonte: acervo do autor.

Importante igualmente registrar, contudo, que a presença destacada de seu Milton nessa imagem não exime de salientar que eventuais homenagens anuais podem esconder - e quase sempre escondem - difíceis e violentas exclusóes no cotidiano ao longo de uma vida inteira. A principal delas é o acesso à saúde: seu Milton é um idoso acometido por doença que lhe coloca na condiçáo de dependência parental para sua locomoção e o cuidado com a saúde, em uma região onde não há atendimento médico permanente. É importante observar as contradiçôes dessa realidade em contraste a outras esferas da vida social, especialmente no que se refere à vulnerabilidade em que se encontra. Trata-se de um trabalhador que vivenciou a exploração do trabalho no campo e teve negado o direito produtivo e reprodutivo da vida, o acesso à saúde, à terra, à cidadania, à educaçáo, à própria memória. De todo modo, resiste, inventa, cria direitos, inclusive no campo da cultura. 


\section{Considerações Finais}

O estudo problematizou a trajetória de vida de um idoso, guardião do pássaro Jaçaná, no campo da criação e organização e defesa da festa no Mocambo do Arari, com perspectivas de identificação e resistência contra as diversas formas de opressão, reivindicando o direito à memória, às sociabilidades e ao lazer. As narrativas de seu Milton Almeida evidenciam sua trajetória de resistência social e cultural; de trabalhadores com saberes e atividades combinadas em diversas áreas - pescadores, agricultores, artesãos, lenhadores -, que ainda assim encontraram tempo e disposição para organizar e brincar na festa do pássaro. Sáo sujeitos sociais que apostam em suas referências culturais próprias por um mundo ético e mais bonito.

O debate histórico produzido pelas experiências narrativas de seu Milton retrata uma história repleta de anseios, sonhos e desilusôes que fazem parte do enredo de cada um, alcançando a multiplicidade de sujeitos e suas interpretaçóes na luta pelo direito de viver bem, ao assumirem o protagonismo de contestação e transformação social. Nesta perspectiva, a revalorização das experiências de sujeitos históricos, em seus fazeres sociais, contribui para o debate e pluralização das fontes históricas, quando sujeitos históricos comuns, com pouca alfabetização, moradores de comunidades rurais, costumam ser segregados e visualizados sob estigmas, como o de "vitimismo", frequentemente propagados pela grande mídia. Pensa-se aqui a perspectiva histórica que compreende o debate pelos mais velhos em suas interpretaçóes sobre os fatos, em um campo de pesquisa que se apresente sem exclusóes, isto é, como um exercício de encontro de experiências sociais.

A importância histórica de resistência para a manutenção da festa do pássaro também se dá como construçáo da identidade dos moradores mais velhos, ao possibilitar os sentidos de pertença social, justificados nas dimensóes de solidariedade, eventualmente organizados em puxirum, também entendido como luta pela cidadania, tecida em experiências sociais, por meio do aspecto festivo, em que se verifica a cultura forjada historicamente.

A pesquisa possibilitou analisar o processo de rememoração. Mais do que reviver o passado dos tempos de juventude e imagens dessa época, também alcança a fase idosa sob outros olhares e emoçóes, isto é, nunca de um passado imutável, pois "o passado se conserva, e além de conservar-se, atua no presente, mas não de forma homogênea" (Bosi, 1994, p. 48). Portanto, um passado repleto de consciência e significados evocados pelo presente, cujas experiências abordadas são testemunhos do tempo histórico, em contradiçóes, rupturas e continuidades, superando a ideia da velhice como um problema frente à perda da vitalidade física e emocional. Do contrário, o passado se perderia pelo silenciamento. 


\section{Referências}

ALBUQUERQUE, Gerson Rodrigues de. Trabalhadores do Muru: o rio das cigarras (1970 - 90). Rio Branco: Edufac, 2005.

ANDRADE, Moacir Couto de. Alguns aspectos da Antropologia Cultural do Amazonas. Manaus: Casa Editora Madrugada, 1978.

ASSAYAG, Simão. Caprichoso, o boi de Parintins. Manaus: Simão Assayag, 1997.

BAKHTIN, Mikhail. A cultura popular na Idade Média e no Renascimento: o contexto de François Rebelais. 4. ed. São Paulo: Hicetec; Brasília: Editora da Universidade de Brasília, 1999.

BANDEIRA, Maria de Lourdes. Território negro em espaço branco. São Paulo: Editora Brasiliense, 1988.

BARRETO, Maria Lectícia Fonseca. Admirável mundo velho: velhice, fantasia e realidade social. São Paulo: Ática, 1992.

BENJAMIN, Walter. Sobre o conceito de história. In: BENJAMIN, Walter. Magia e técnica, arte e política. São Paulo: Brasiliense, 1985. p. 222-232. (Obras Escolhidas, v. 1).

BOSI, Ecléa. Memória e sociedade: lembranças de velhos. 3. ed. São Paulo: Companhia das Letras, 1994.

BRAGA, Sérgio Ivan Gil. Os bois-bumbás de Parintins. Rio de Janeiro: Funarte: Editora da Universidade Federal do Amazonas, 2002.

CANDIDO, Antonio. Os parceiros do Rio Bonito: estudo sobre o caipira paulista e a transformaçáo dos seus meios de vida. 10. ed. São Paulo: Duas Cidades: Editora 34, 2003.

CARNEIRO, Edison. A cidade de Salvador, 1549: uma reconstituição histórica; A conquista da Amazônia. 2. ed. Rio de Janeiro: Civilização Brasileira; Brasília: INL, 1980. (Coleção Retratos do Brasil, v. 146).

CERQUA, Dom Arcângelo. Claróes de fé no Médio Amazonas. 2. ed. Manaus: Prograf, 2009.

CHARONE, Olinda. O teatro dos pássaros como uma forma de espetáculo pós-moderno. Revista Ensaio Geral, Belém, v. 1, n. 1, jan./jun. 2009.

COSTA, Selda Vale da. Boi-bumbá, memória de antigamente. Somanlu: Revista de Estudos Amazônicos, Manaus, v. 2, n. 2, p. 147-153, maio 2002.

FIGUEIREDO, Sílvio Lima; TAVARES, Auda Piani. Mestres da cultura. Belém: Edufpa, 2006.

FUNES, Eurípedes. Nasci nas matas, nunca tive Senhor: história e memória dos mocambos do baixo Amazonas. In: REIS, João José; GOMES, Flávio dos Santos (Org.). Liberdade por um fio: uma história dos quilombos no Brasil. São Paulo: Companhia das Letras, 1996. p. 467-497.

GALVÃO, Eduardo. Santos e visagens: um estudo da vida religiosa de Itá, Baixo Amazonas. 2. ed. São Paulo: Editora Nacional; Brasília: INL, 1976.

GOMES, Jessica Dayse Matos. Mocambos na Amazônia: História e identidade étnico-racial do Arari, Parintins/Amazonas. Dissertação (Mestrado em Sociedade e Cultura na Amazônia) - 
UFAM, Manaus, AM, 2017.

GONZALEZ, Lélia. Mulher Negra. Afrodiáspora, São Paulo, ano 3, n. 6-7, p. 177-198, 1994.

GUARINELLO, Norberto Luiz. Festa, trabalho e cotidiano. In: JANCSÓ, István; KANTOR, Iris (Org.). Festa: cultura \& sociabilidade na América Portuguesa. v. II. São Paulo: Hucitec: Editora da Universidade de São Paulo: Fapesp: Imprensa Oficial, 2001. p. 969-975.

JOUTARD, Philippe. Desafios à história oral do século XXI. In: FERREIRA, Marieta de Moraes; FERNANDES, Tania Maria; ALBERTI, Verena (Org.). História oral: desafios para o século XXI. Rio de Janeiro: Editora Fiocruz: Casa de Oswaldo Cruz: CPDOC: Fundação Getúlio Vargas, 2000. p. 31-45.

LOUREIRO, Joâo de Jesus Paes. Cultura amazônica: uma poética do imaginário. Belém: Cejup, 2001.

MAUÉS, Raymundo Heraldo; VILLACORTA, Gisela Macambira. Pajelança e encantaria a Amazônica. In: PRANDI, Reginaldo (Org.). Encantaria brasileira: o livro dos mestres, caboclos e encantados. Rio de Janeiro: Pallas, 2011. p. 11-58.

MEDEIROS, Mônica Xavier de. "Tudo era um puxirum, era aquela... era mulher, era homem que ia roçar": a cultura do puxirum em comunidades rurais de Vila Amazônia - Parintins (AM). In: FERREIRA, Arcângelo da Silva. et al. (Org.). Pensar, fazer e ensinar: desafios para o ofício do historiador no Amazonas. Manaus: UEA Ediçóes: Valer, 2015. p. 49-65.

MENEZES, Bruno de. Obras completas de Bruno de Menezes. Belém: Secretaria Estadual de Cultura: Conselho Estadual de Cultura, 1993.

MOURA, Carlos Eugênio Marcondes de. O teatro que o povo cria: cordão de pássaros, cordão de bichos e pássaros juninos do Pará - da dramaturgia ao espetáculo. Belém: Secult, 1997.

POLLAK, Michael. Memória e identidade social. Estudos Históricos, Rio de Janeiro, v. 5. n. 10, p. 200-212, 1992.

POLLAK, Michael. Memória, esquecimento, silêncio. Estudos Históricos. Rio de Janeiro, v. 2. n. 3, p. 3-15, 1989.

PORTELLI, Alessandro. O que faz a história oral diferente. Projeto História: Revista do Programa de Estudos Pós-Graduados de História, São Paulo, v. 14, p. 25-39, 1997a.

PORTELLI, Alessandro. Tentando aprender um pouquinho: algumas reflexôes sobre a ética na história oral. Projeto História: Revista do Programa de Estudos Pós-Graduados de História, São Paulo, v. 15, p. 13-49, 1997 b.

SALLES, Vicente. Épocas do teatro no Grão-Pará, ou, Apresentação do teatro de época. Belém: UFPA, 1994.

SAUNIER, Tonzinho. O magnifico folclore de Parintins. Manaus: Edições Parintintin, 1989.

SILVA, Adan Renê Pereira da Silva; LIMA JÚNIOR, Josivaldo Bentes; MASCARENHAS, Suely Aparecida do Nascimento. O cordão de pássaros do Mocambo do Arari: reflexóes sobre gênero por intermédio da cultura popular. Revista Expressāo Católica, v. 8, n. 2, p. 92-101, 2019.

SILVA, Charlene Maria Muniz da. Mocambo, Caburi e Vila Amazônia no município de Parintins: múltiplas dimensóes do rural e do urbano na Amazônia. Dissertação (Mestrado em Geografia) - 
UFAM, Programa de Pós-Graduação em Geografia, Manaus, AM, 2009.

SILVA, Jamilly Souza da. A festa de São Benedito no bairro da Praça 14. In: SAMPAIO, Patrícia Melo (Org.). O fim do silêncio: presença negra na Amazônia. Belém: Açaí/CNPq, 2011. p. 173190.

SILVA, Julio Claudio da; TORRES, Iraíldes Caldas. Memórias amazônicas nas narrativas de pescadoras de camarão da comunidade São Sebastião da Brasília, Parintins-AM. História Oral, v. 22, n. 1, p. 81-101, 2019.

SOSSAI, Fernando Cesar; COELHO, Ilanil. História oral, cidade e lazer no tempo presente. História Oral, v. 17, n. 1, p. 7-37, 2014.

THOMPSON, Edward Palmer. Costumes em comum: estudos sobre a cultura popular tradicional. São Paulo: Companhia das Letras, 1998.

TOMELIN JR., Nelson. "Eu compreendo": Thompson, experiência e o trabalho da linguagem por velhos participantes do debate histórico. Projeto História: Revista do Programa de Estudos Pós-Graduados de História, São Paulo, v. 48, 2013.

TOURTIER-BONAZZI, Chantal de. Arquivos: propostas metodológicas. In: AMADO, Janaína; FERREIRA, Marieta Moraes de (Org.). Usos \& abusos da história oral. 8. ed. Rio de Janeiro: Editora FGV, 2006. p. 233-245.

TURNER, Victor Witter. Do ritual ao teatro: a seriedade humana de brincar. Tradução Michele Markowitz e Juliana Romeiro. Rio de Janeiro: Editora UFRJ, 2015.

\section{Fontes Orais}

ALMEIDA, Milton Almeida [83 anos]. [set. 2017]. Entrevistador: Josivaldo Bentes Lima Júnior. Mocambo do Arari, Parintins, AM, 5 set. 2017.

Recebido em 01/03/2021.

Versão final reapresentada em 20/04/2021.

Aprovado em 04/05/2021.

Fonte de financiamento: Coordenação de Aperfeiçoamento de Pessoal de Nível Superior (Capes) - Bolsa.

Conflitos de interesse: nada a declarar. 